African Crop Science Journal by African Crop Science Society is licensed under a Creative Commons Attribution 3.0 Uganda License. Based on a work at www.ajol.info/ and www.bioline.org.br/cs DOI: https://dx.doi.org/10.4314/acsj.v28i3.3

\title{
PORTABLE PCR FIELD-BASED DETECTION OF SWEETPOTATO VIRUSES
}

\author{
J. SSENGO, P. WASSWA, S.B. MUKASA, A. OKIROR and S. KYAMANYWA
}

School of Agricultural Sciences, College of Agricultural and Environmental Sciences, Makerere University, P. O. Box 7062, Kampala, Uganda

Corresponding author: jssengo@ caes.mak.ac.ug

(Received 27 February 2020; accepted 31 August 2020)

\begin{abstract}
Sweetpotato (Ipomoea batatas Lam.) production is greatly constrained by viral infections, especially Sweet potato feathery mottle virus and Sweet potato chlorotic stunt virus that synergistically cause a severe sweetpotato virus disease. The impact of viruses is aggravated by the vegetative nature of the crop and inaccessibility to dependable diagnostic tools in rural areas where sweetpotato production is done. This makes it hard for seed inspectors to perform quality checks prior to use of vines for planting. The objective of this study was to develop a procedure that allows for detection of sweetpotato viruses on-site. This involved modification of the Lodhi et al. (1994) nucleic acid extraction procedure, by omitting some of the laboratory specific steps and varying the incubation time in liquid nitrogen, instead of the freezer. Incubation in liquid nitrogen for only 1.5 hours yielded as high quality RNA compared to that of the original protocol, when incubation was done at $4{ }^{\circ} \mathrm{C}$ overnight in a freezer. Reverse transcriptase (RT) was run using a portable miniPCR thermocycler; and the resulting cDNA was amplified using this miniPCR machine instead of using a laboratory stationed conventional PCR thermocycler. The cDNA was efficiently amplified and amplicons were similar to those obtained with the original extraction protocol and subsequent amplification by the conventional RT-PCR. Our protocol reduced extraction time from about 16 hours for the original protocol, to about 2 hours and 45 minutes. If this tool is utilised by the crop protection departments, we believe it will contribute greatly towards sustainable sweetpotato production through making timely recommendations.
\end{abstract}

Key Words: Incubation, liquid nitrogen, miniPCR

\section{RÉSUMÉ}

La production de la patate douce (Ipomoea batatas Lam.) est fortement limitée par les infections virales, en particulier le virus de la marbrure plumeuse de la patate douce et le virus du stunt chlorotique de la patate douce qui provoquent en synergie une maladie virale grave de la patate douce. L'impact des virus est aggravé par la nature végétative de la culture et l'inaccessibilité des outils fiables pour le diagnostic dans les zones rurales où la production de patate douce est réalisée. Cela rend difficile les inspecteurs des semences d'effectuer des contrôles de qualité avant l'utilisation des vignes par les agriculteurs. L'objectif de cette étude était de développer une procédure permettant la détection des 
virus de la patate douce sur place. Cela impliquait une modification de Lodhi et al. (1994) procédure d'extraction d'acide nucléique, en omettant certaines des étapes spécifiques du laboratoire et en faisant la variation de temps d'incubation dans l'azote liquide, au lieu du congélateur. L'incubation dans l'azote liquide pendant seulement 1,5 heure a donné un ARN de haute qualité comme le protocole d'origine, lorsque l'incubation a été effectuée à $4{ }^{\circ} \mathrm{C}$ pendant une nuit dans un congélateur. La transcriptase inverse (RT) a été faite en utilisant un thermocycleur mini PCR portable et l'ADNc, et résultant a été amplifié en utilisant cette machine mini PCR au lieu d'utiliser un thermocycleur PCR conventionnel stationné en laboratoire. L'ADNc a été efficacement amplifié et les amplicons étaient similaires à ceux obtenus avec le protocole d'extraction original et l'amplification ultérieure par la RTPCR conventionnelle. Notre protocole a réduit le temps d'extraction d'environ 16 heures pour le protocole d'origine, à environ 2 heures et 45 minutes. Si cet outil est utilisé par le département de la protection des cultures, nous pensons qu'il contribuera grandement à la production durable de patate douce en faisant des recommandations en temps opportun.

Mots Clés: Incubation, azote liquide, mini PCR

\section{INTRODUCTION}

Sweetpotato (Ipomoea batatas Lam.) production is greatly constrained by viral infections. More than 30 viruses have been detected to infect sweetpotato worldwide (Clark et al., 2012), out of which 23 are formally recognised by the International Committee on Taxonomy of Viruses (Kwak et al., 2014). This number is expected to increase with improvement in virus detection methods (Kwak et al., 2014).

Sweet potato feathery mottle virus (SPFMV: Potyvirus; Potyviridae) and Sweet potato chlorotic stunt virus (SPCSV; Crinivirus; Closteroviridae) are globally the most common and important viruses infecting sweetpotato (Aritua et al., 2007; Wasswa et al., 2011; Adikini et al., 2016). SPCSV coinfects with SPFMV, causing sweetpotato virus disease (SPVD), which results in up to 95\% yield reduction (Gibson et al., 1998; Adikini et al., 2016). Damage caused by single viral infections has been assayed extensively. In a study by Adikini et al. (2016), sweetpotato plots infected with SPFMV alone yielded $40 \%$ less than the healthy control; while infection of sweetpotato by SPCSV alone resulted in yield losses of up to $52 \%$. Mukasa et al. (2006) also found out that SPCSV alone causes up to $54 \%$ yield reduction in sweetpotato.
Thus, any strategy to control these two viruses dually, is expected to contribute a lot towards sustainable sweetpotato productivity.

In SPVD infections, plants are severely stunted, with severe chlorosis (Gibson et al., 1998; Mukasa et al., 2003), so farmers easily select against such plants for subsequent planting (Aritua et al., 1999). In single sweetpotato virus infections, symptoms are mostly not visible (Mukasa et al., 2006) and so the sweetpotato vines appear healthy. This influences farmers to pick such vines, thus spreading viral inocula through vine cuttings. Additionally, in Uganda, programmes aimed at enhancing food security often use farmerderived planting materials, whose health status depends on visible symptoms.

These challenges could be addressed by appropriate diagnosis. However, considering that the equipment for this is laboratory based, makes the problem persist, in light of the fact that only a few of such laboratories are available in the country. This problem is heightened by the fact that most vine multiplication by nursery operators is done near farmers localities', thus making it difficult for quality checks by certifying bodies and extension workers. Furthermore, the distance associated with moving samples from the field to laboratories exposes them to degradation, and to a possibility of faulty analytical results. SPFMV 
and SPCSV have RNA genomes (Sakai et al., 1997; Kreuze et al., 2002) and are, thus more prone to degradation during sample transportation. The above challenges could be mitigated by exploring portable field-based detection methods for viral infections, with potential to give timely results.

Nucleic acid extraction and PCR procedures can be modified for tests to be easily and quickly done in the field. A simple DNA amplification for diagnostic assay, utilising a miniPCR where there is no laboratory, has been developed (Guevara et al., 2018). In Nigeria, this miniPCR was used to detect protozoan malaria parasites (Oguzie et al. Unpublished). However, the use of miniPCR to detect viruses, including the more erratic RNA viruses, has not been done. This paper reports a simple modified field-based nucleic acid extraction protocol and on-site detection method for key sweetpotato viruses using a miniPCR pathway.

\section{MATERIALS AND METHODS}

Source of virus isolates. Two RNA viruses, namely SPCSV (East Africa strain; GenBank accession no. DQ864362) (Aritua et al., 2008) and SPFMV (East Africa strain; GenBank accession no. FJ795762) (Tugume et al., 2010), were used in this study. These viruses were obtained from sweetpotato virus reversion PEARL project (ID OPP1112152) at Makerere University Research Institute, Kabanyolo (MUARIK). The virus isolates were partially sequenced to confirm identity [primers (hylaboratories, Israel) (Table 1). The isolates for these two viruses were maintained in Ipomoea setosa as the source of inoculum, in an insect proof screen house at MUARIK.

Plant material and screening for virus-free status. Sweetpotato cultivar Beauregard, which is highly susceptible to virus infections (Ssamula et al., 2020), and the indicator plant Ipomoea setosa (Moyer and Salazar, 1989; Wasswa et al., 2011) were used in this study. Cultivar Beauregard was obtained from the

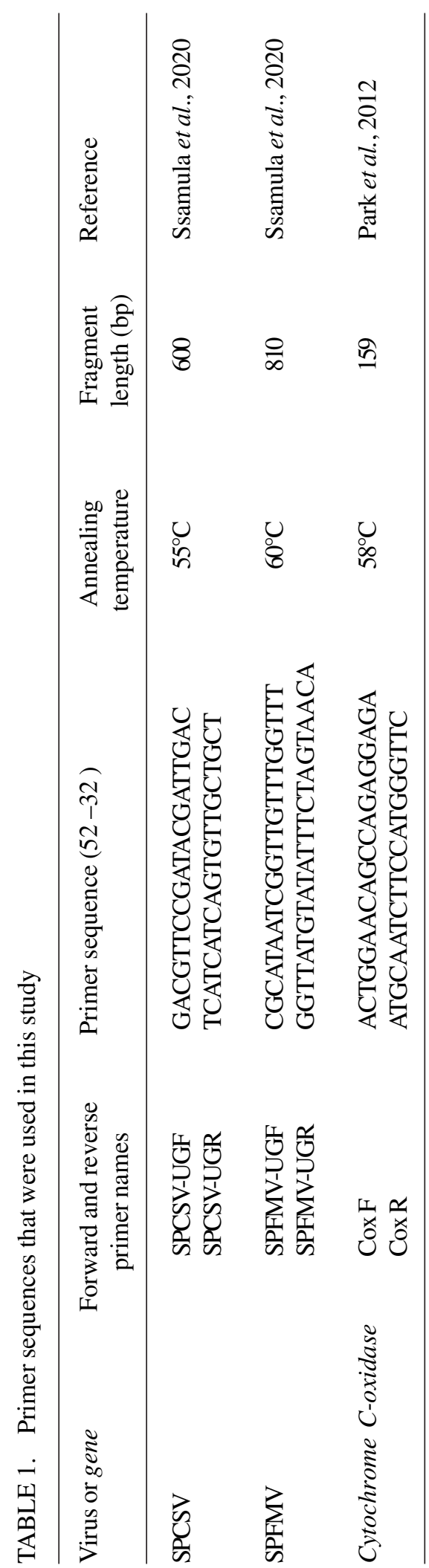


tissue culture weaned plants at MUARIK. The selected plants of cv. Beauregard and I. setosa were established in pots with about $2.5 \mathrm{~kg}$ of sterilised soil mixture (3:1:1 ratio of black soil: lake sand: cow manure) in a screenhouse at MUARIK. Beauregard and I. setosa plants were tested for SPCSV and SPFMV using conventional RT-PCR to confirm healthy status (primers listed in Table 1). The house keeping gene, Cytochrome C Oxidase, was used to confirm reactions (primers in Table 1). Routine spraying of screenhouse plants with imidacloprid and cypermethrin was done to wall off insect vectors for sweetpotato viral infections.

Virus inoculation of experimental plants. Nine healthy plants of cv. Beauregard and one plant of I. setosa were singly infected with isolates of SPCSV and SPFMV, by side grafting using infected I. setosa scions. These graftinoculated plants served as experimental plants at laboratory level for the development and optimisation of portable miniPCR field-based protocols for identification of sweetpotato viruses.

\section{Development of portable PCR field-based protocols}

RNA extraction. RNA was extracted from leaf samples obtained from plants, independently infected with SPCSV and SPFMV, using the method mostly used for nucleic acid extraction from sweetpotato plants; the CTAB method originally described by Lodhi et al. (1994) with modifications to fit field conditions. From each plant, a composite sample of bottom, middle and top leaves was taken for extraction work.

Extraction buffer. A modified CTAB extraction buffer containing (2\% (w/v) CTAB, $2 \%$ polyvinyl pyrrolidine (PVP-40), $1.4 \mathrm{M}$ $\mathrm{NaCl}, 20 \mathrm{mM}$ EDTA, and $100 \mathrm{mM}$ Tris-HCl, PH 8.0), was preheated to $60{ }^{\circ} \mathrm{C}$ for 10 minutes. Then, fresh $0.2 \%(\mathrm{v} / \mathrm{v}) 2$ mercaptoethanol was added.
RNA extraction procedure. Three fresh leaf discs from infected plants were placed inside a thick gauged plastic bag and stored in liquid nitrogen prior to grinding. The fresh infected tissue was then ground using a roller and mixed with 10 volumes $(1 \mathrm{ml})$ of CTAB extraction buffer. The resultant sap was decanted into a $1.5 \mathrm{ml}$ eppendorf tube and incubated at $65^{\circ} \mathrm{C}$ in a water bath, heated using a portable gas cylinder for 10-15 minutes. After incubation, the materials were centrifuged in tubes at maximum speed of $12000 \mathrm{rpm}$ in a Gyro-micro-centrifuge for 5 minutes. Then, $700 \mu \mathrm{l}$ of clarified sap was removed; placed in a fresh $1.5 \mathrm{ml}$ eppendorf tube and an equal volume of Chloroform: Isoamyl alcohol (24:1) added and mixed to emulsion by inverting the tube about 30 times.

The mixture was centrifuged at maximum speed of $12000 \mathrm{rpm}$ in a Gyro-micro-centrifuge for 10 minutes. The upper aqueous layer of about $600 \mu \mathrm{l}$ was carefully removed and transferred to a fresh eppendorf tube. An equal volume of chloroform: Isoamyl alcohol was added, mixed and spun as described above. An aqueous layer was removed from the spun mixture, taking care not to disturb the interphase. An equal volume of $6 \mathrm{M} \mathrm{LiCl}$ was added.

The mixture was incubated in liquid nitrogen for 2, 1.5, 1:15 and $1 \mathrm{hr}$; and 45 and 30 minutes. This step was done for these different time intervals in liquid nitrogen. The control was the sample incubated at $4{ }^{\circ} \mathrm{C}$ for overnight.

After incubation, the mixture was spun at room temperature, at $12000 \mathrm{rpm}$ for 25 minutes to pellet out the RNA. The aqueous layer was decanted off and the pellet in the eppendorf tubes was washed with $400 \mu 175 \%$ ethanol; followed by spinning at $12000 \mathrm{rpm}$ for 10 minutes. Ethanol was then decanted off and the eppendorf tube spun for 1 minute at $8000 \mathrm{rpm}$ to down the ethanol, and the pellet air dried for 40 minutes. Finally, the pellet was re-suspended in $100 \mu \mathrm{l}$ of molecular-biology grade water previously heated at $65^{\circ} \mathrm{C}$ for 15 minutes. Finally, after the extraction process, 
the quality and quantity of RNA were determined using a NanoDrop ${ }^{\circledR}$ ND-1000 Spectrophotometer (Thermo Scientific; Bargel Analytical Instruments, Airport City, Israel). The RNA integrity was checked using $1.2 \%$ gel electrophoresis.

Complementary DNA (cDNA) synthesis. The PCRBio Maxima First Strand cDNA synthesis kit (Thermo Scientific, Tamar, Israel) was used in the synthesis of cDNA, following the manufacturer's manual. Basically, the 10 $\mu \mathrm{l}$ PCR reaction mixture used included $0.5 \mu \mathrm{l}$ of 20x RTase, $2 \mu \mathrm{l}$ of 5x cDNA synthesis mix, containing anchored oligo (dT), random hexamers, $15 \mathrm{mM} \mathrm{MgCl}, 5 \mathrm{mM}$ dNTPs, enhancers and stabilisers], $4.5 \mu \mathrm{l}$ of SDW and $3 \mu \mathrm{l}$ of 1:10 fold diluted RNA extract. The PCR condition for cDNA synthesis was a two-step and included heating at $42{ }^{\circ} \mathrm{C}$ for 30 minutes and $85^{\circ} \mathrm{C}$ for 10 minutes. The cDNA synthesis was done using a portable miniPCR thermocycler, with dimensions of $(5.1 \mathrm{~cm} \times$ $12.7 \mathrm{~cm}$ ) and a weight of $450 \mathrm{~g}$ (Amplyus, Massachusetts - USA, Mini8 4485). The miniPCR was programmed via an application (mini8 v2) that was downloaded from miniPCR product store and installed on an android phone (SM-J530F).

cDNA amplification. The cDNA for SPCSV, SPFMV and housekeeping gene (Cytochrome $C$-oxidase) was amplified in the Amplyus miniPCR thermocycler, instead of the conventional PCR thermocycler. The PCR was done in a $10 \mu \mathrm{l}$ master mix of $3 \mu \mathrm{l}$ of molecular grade water, $5 \mu$ of PCR mix (HyLabs Ready Mix (2X), HyLabs, Rehovot, Israel), $0.5 \mu$ of each primer (10 pmol) (Table 1) and $1 \mu \mathrm{l}$ of cDNA (1000 $\left.\mathrm{ng} \mathrm{\mu l}^{-1}\right)$.

The PCR condition for SPCSV included an initial heating step at $94{ }^{\circ} \mathrm{C}$ for 3 minutes; 30 cycles of $94^{\circ} \mathrm{C}$ for $30 \mathrm{~s}, 55^{\circ} \mathrm{C}$ for $30 \mathrm{~s}$ and $72{ }^{\circ} \mathrm{C}$ for $45 \mathrm{~s}$; and final extension step of 72 ${ }^{\circ} \mathrm{C}$ for 10 minutes. The PCR condition for SPFMV included an initial heating step at 95
${ }^{\circ} \mathrm{C}$ for 5 minutes; 35 cycles of $95^{\circ} \mathrm{C}$ for $30 \mathrm{~s}$, $60{ }^{\circ} \mathrm{C}$ for $40 \mathrm{~s}$ and $72{ }^{\circ} \mathrm{C}$ for $40 \mathrm{~s}$; and final extension step of $72{ }^{\circ} \mathrm{C}$ for 8 minutes. The PCR condition for the housekeeping gene Cytochrome C Oxidase, (Cox) included an initial heating step at $94{ }^{\circ} \mathrm{C}$ for 4 minutes; 30 cycles of $94{ }^{\circ} \mathrm{C}$ for $30 \mathrm{~s}, 60^{\circ} \mathrm{C}$ for $30 \mathrm{~s}$ and 72 ${ }^{\circ} \mathrm{C}$ for $30 \mathrm{~s}$; and final extension step of $72{ }^{\circ} \mathrm{C}$ for 5 minutes.

\section{Gel electrophoresis and documentation of} PCR products. A portable electrophoresisBlueGel-documentation unit with dimensions of $23 \mathrm{~cm} \times 10 \mathrm{~cm} \times 7 \mathrm{~cm}$ and weight of 350 $\mathrm{g}$ (Amplyus, Massachusetts - USA) was used. Analysis of the PCR products was done using $1.0 \%$ agarose in $1 \mathrm{x}$ TBE (Tris-borate -EDTA) buffer. Gels were stained with Gel-Green ${ }^{\mathrm{TM}}$ DNA stain (CA, USA), using a 1:10,000 dilution. Four microlitres of PCR products were loaded on the gel and run at a current of $48 \mathrm{~V}$ for 30 minutes.

The PCR products were viewed under imaging and documentation 'fold a view hood' placed on top of the orange cover on top of the BlueGel ${ }^{\mathrm{TM}}$ base. Using a phone camera, the image of the PCR products was taken and stored; after which the image was processed for virus presence or absence.

Source of power in the field. The miniPCR thermocycler is supplied with a power pack (MP-20000A lithium polymer battery; Amplyus, Massachusetts - USA) in case of limited access to the alternate current (AC). Additional power needed to run the BlueGel unit and a Gyro micro-centrifuge (which do not use the power pack) was generated from direct current (DC) from a portable 60-watt solar panel (Solar Now Uganda Company) weighing $1.63 \mathrm{~kg}$. To convert from DC to AC, a portable inverter $(300 \mathrm{~V})$ (Solar Now Uganda) was used. Heating the extraction buffer to $65^{\circ} \mathrm{C}$ was done using a Total Ugandafuel station $6 \mathrm{~kg}$ gas cylinder. 


\section{RESULTS}

RNA quantity and quality. The modified CTAB extraction protocol used fewer and shorter steps, thus reducing total time of extraction from overnight ( 16 hours) to 2 hours and 45 minutes. Incubation in liquid nitrogen for 2 or 1.5 hours yielded RNA of concentrations not significantly different from sample extracts incubated at $4{ }^{\circ} \mathrm{C}$ for overnight (Table 2). For these two incubation periods, the RNA concentrations were between

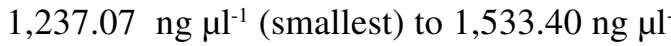
${ }^{1}$ (highest) for SPFMV infected samples; while the RNA concentration for SPCSV infected plant samples ranged from 1156.73 to $1,498.73$ ng $\mu \mathrm{l}^{-1}$. The range of RNA concentration for the control (sample extracts incubated at $4{ }^{\circ} \mathrm{C}$ ) for the SPFMV and SPCSV infected samples were 1201.57-1515.97 and 1156.73-1498.67 ng $\mu^{-1}$, respectively (Table 3 ). Lowering the incubation period below 1.5 hours in liquid nitrogen greatly compromised RNA concentration and purity (Table 3). Compared to the original protocol, the extracted RNA with our modified protocol showed good integrity (Fig. 1).

PCR analysis. Successful and reproducible amplicons of $810 \mathrm{bp}$ and $600 \mathrm{bp}$, respectively, for SPFMV and SPCSV, were obtained with our modified extraction protocol, for samples incubated in liquid nitrogen for 1.5 hours and using RT-miniPCR [(Fig. 2 (a-d)]; and these were not in any way an alteration to the depiction of the amplicons from the original protocol (Fig. 2 (e-h).

\section{DISCUSSION}

RNA extraction. It is clear that the RNA extraction protocol described in this report (Fig. 1) was much faster, technically easier and can be carried out even in remote areas, where power supplies may be a challenge. This contrasts considerably with the existing RNA

TABLE 2. Means for 260/280 RNA/protein contamination, A260/A230 ratio (chaotropic salt contamination and RNA concentration

\begin{tabular}{|c|c|c|c|c|c|c|c|}
\hline \multirow[t]{2}{*}{ Category } & \multirow{2}{*}{$\begin{array}{l}\text { Incubation } \\
\text { time (min) }\end{array}$} & \multicolumn{2}{|c|}{$260 / 280$} & \multicolumn{2}{|c|}{$260 / 230$} & \multicolumn{2}{|c|}{ RNA Conc $\left(n g \mu l^{-1}\right)$} \\
\hline & & SPFMV & SPCSV & SPFMV & SPCSV & SPFMV & SPCSV \\
\hline \multirow[t]{3}{*}{$4{ }^{\circ} \mathrm{C}$} & Overnight & $1.959^{\mathrm{a}}$ & $2.076^{\mathrm{a}}$ & $1.810^{\mathrm{a}}$ & $1.871^{\mathrm{a}}$ & $1373.637^{\mathrm{a}}$ & $1346.657^{\mathrm{a}}$ \\
\hline & 120 & $1.997^{\mathrm{a}}$ & $2.069^{\mathrm{a}}$ & $1.860^{\mathrm{a}}$ & $1.828^{\mathrm{a}}$ & $1358.903^{\mathrm{a}}$ & $1342.817^{\mathrm{a}}$ \\
\hline & 90 & $1.978^{\mathrm{a}}$ & $2.069^{\mathrm{a}}$ & $1.852^{\mathrm{a}}$ & $1.799^{\mathrm{a}}$ & $1351.977^{\mathrm{a}}$ & $1335.633^{\mathrm{a}}$ \\
\hline \multirow[t]{4}{*}{ Liquid nitrogen } & 75 & $0.527^{b}$ & $0.582^{b}$ & $0.424^{\mathrm{b}}$ & $0.533^{b}$ & $36.655^{\mathrm{b}}$ & $57.085^{\mathrm{b}}$ \\
\hline & 60 & $0.046^{c}$ & $0.076^{c}$ & $0.052^{c}$ & $0.079^{c}$ & $1.982^{\mathrm{c}}$ & $0.594^{c}$ \\
\hline & 45 & $0.003^{\mathrm{c}}$ & $0.004^{\mathrm{d}}$ & $0.002^{\mathrm{c}}$ & $0.006^{\mathrm{d}}$ & $0.005^{c}$ & $0.008^{c}$ \\
\hline & 30 & $0.000^{c}$ & $0.000^{\mathrm{d}}$ & $0.000^{c}$ & $0.000^{\mathrm{d}}$ & $0.000^{c}$ & $0.000^{c}$ \\
\hline Mean & & 0.930 & 0.982 & 0.857 & 0.874 & 588.456 & 583.256 \\
\hline s.e & & & 0.018 & & 0.023 & & 12.41 \\
\hline $\operatorname{LSD}_{0.05}$ & & & 0.051 & & 0.065 & & 34.51 \\
\hline $\mathrm{CV}(\%)$ & & & 14.8 & & 20.8 & & 16.4 \\
\hline
\end{tabular}

S.e $=$ the standard error of the mean, $\mathrm{LSD}=$ least significant difference and $\mathrm{CV}(\%)=$ percentage coefficient of variation. Means within a column that are followed by the same superscript are not significantly different at $5 \%$ significance level 
TABLE 3. RNA concentration and purity determined by overnight incubation at $4{ }^{\circ} \mathrm{C}$ versus incubation in liquid nitrogen for 30 min up to 120 min

\begin{tabular}{|c|c|c|c|c|c|c|c|c|c|c|c|c|c|c|c|c|c|c|c|c|c|c|}
\hline \multirow{4}{*}{$\begin{array}{l}\text { Virus } \\
\text { type }\end{array}$} & \multirow[t]{4}{*}{ Sample } & \multicolumn{21}{|c|}{ Incubation time (min) } \\
\hline & & \multirow{2}{*}{\multicolumn{3}{|c|}{ Overnight }} & \multicolumn{9}{|c|}{$---ー-ー---$ Incubation in liquid nitrogen } & \multicolumn{9}{|c|}{$--------\cdots-\cdots$} \\
\hline & & & & & & 120 & & & 90 & & & 75 & & & 60 & & & 45 & & & 30 & \\
\hline & & $\begin{array}{l}260 / \\
280\end{array}$ & $\begin{array}{l}260 / \\
230\end{array}$ & $\begin{array}{l}\text { RNA } \\
\text { Conc } \\
\left(\mathrm{ng} \mu \mathrm{l}^{-1}\right)\end{array}$ & $\begin{array}{l}260 / \\
280\end{array}$ & $\begin{array}{l}260 / \\
230\end{array}$ & $\begin{array}{l}\text { RNA } \\
\text { Conc } \\
\left(\mathrm{ng} \mu 1^{-1}\right)\end{array}$ & $\begin{array}{l}260 / \\
280\end{array}$ & $\begin{array}{l}260 / \\
230\end{array}$ & $\begin{array}{l}\text { RNA } \\
\text { Conc } \\
\left(\mathrm{ng} \mu \mu^{-1}\right)\end{array}$ & $\begin{array}{l}260 / \\
280\end{array}$ & $\begin{array}{l}260 / \\
230\end{array}$ & $\begin{array}{l}\text { RNA } \\
\text { Conc } \\
\left(\mathrm{ng} \mu \mathrm{l}^{-1}\right)\end{array}$ & $\begin{array}{l}260 / \\
280\end{array}$ & $\begin{array}{l}260 / \\
230\end{array}$ & $\begin{array}{l}\text { RNA } \\
\text { Conc } \\
\left(\mathrm{ng} \mu \mathrm{l}^{-1}\right)\end{array}$ & $\begin{array}{l}260 / \\
280\end{array}$ & $\begin{array}{l}260 / \\
230\end{array}$ & $\begin{array}{l}\text { RNA } \\
\text { Conc } \\
\left(\mathrm{ng} \mu \mathrm{l}^{-1}\right)\end{array}$ & $\begin{array}{l}260 / \\
280\end{array}$ & $\begin{array}{l}260 / \\
230\end{array}$ & $\begin{array}{l}\text { RNA } \\
\text { Conc } \\
\left(\text { ng } \mu 1^{-1}\right)\end{array}$ \\
\hline \multirow[t]{10}{*}{ SPFMV } & B1 & 1.98 & 1.99 & 1361.70 & 2.09 & 1.85 & 1343.57 & 2.04 & 1.75 & 1533.40 & 0.44 & 0.32 & 30.20 & 0.05 & 0.19 & -21.23 & 0.00 & 0.00 & 0.00 & 0.00 & 0.00 & 0.00 \\
\hline & B2 & 2.05 & 2.01 & 1462.87 & 2.05 & 1.90 & 1382.53 & 2.00 & 1.70 & 1339.20 & 0.47 & 0.28 & 69.63 & 0.11 & 0.04 & 0.25 & 0.03 & 0.02 & 0.0 & 0.00 & 0.00 & 0.00 \\
\hline & B3 & 1.97 & 1.89 & 1484.10 & 03 & 1.93 & 1344.13 & 2.03 & 1.91 & 1313.27 & 0.64 & 0.58 & 51.13 & 0.04 & 0.06 & 0.06 & 0.00 & 0.00 & 0.00 & 0.00 & 0.00 & 0.00 \\
\hline & B4 & 1.91 & 1.86 & 1515.97 & 1.95 & 1.90 & 1423.00 & 1.88 & 1.72 & 1355.70 & 0.39 & 0.25 & 10.23 & 0.03 & 0.03 & 0.04 & 0.00 & 0.00 & 0.00 & 0.00 & 0.00 & 0.00 \\
\hline & B5 & 1.98 & 1.92 & 1424.63 & 1.86 & 1.88 & 1531.53 & 1.85 & 1.92 & 1325.27 & 0.24 & 0.32 & 16.10 & 0.10 & 0.14 & 0.69 & 0.00 & 0.00 & 0.00 & 0.00 & 0.00 & 0.00 \\
\hline & B6 & 2.02 & 1.94 & 1282.73 & 1.90 & 1.65 & 1280.13 & 1.95 & 1.88 & 1344.43 & 0.30 & 0.27 & -54.20 & 0.01 & 0.03 & 0.18 & 0.00 & 0.00 & 0.0 & 0.00 & 0.00 & 0.00 \\
\hline & B7 & 1.90 & 1.65 & 1220.90 & 1.94 & 1.99 & 1328.47 & 2.05 & 1.97 & 1390.87 & 1.07 & 0.56 & 44.48 & 0.05 & 0.01 & 0.09 & 0.00 & 0.00 & 0.00 & 0.00 & 0.00 & 0.00 \\
\hline & B8 & 1.89 & 1.62 & 1417.93 & 2.07 & 1.94 & 1375.47 & 1.95 & 1.85 & 1361.37 & 0.61 & 0.72 & 32.27 & 0.00 & 0.00 & 0.00 & 0.00 & 0.00 & 0.00 & 0.00 & 0.00 & 0.00 \\
\hline & B9 & 1.92 & 1.40 & 1363.97 & 2.06 & 1.62 & 1343.13 & 1.98 & 1.90 & 1311.30 & 0.36 & 0.53 & 10.73 & 0.05 & 0.02 & 0.04 & 0.00 & 0.00 & 0.01 & 0.00 & 0.00 & 0.00 \\
\hline & $\mathrm{Se}$ & 1.96 & 1.83 & 1201.57 & 2.01 & 1.93 & 1237.07 & 2.04 & 1.92 & 1244.97 & 0.75 & 0.42 & 66.83 & 0.00 & 0.01 & 0.07 & 0.00 & 0.00 & 0.00 & 0.00 & 0.00 & 0.00 \\
\hline \multirow[t]{10}{*}{ SPCSV } & B1 & 2.10 & 1.88 & & & 1.72 & & & 1.62 & & & 0.44 & 87.73 & 0.03 & 0.04 & & 0.00 & 0.00 & 0.00 & 0.00 & 0.00 & 0.0 \\
\hline & B2 & 2.15 & 1.82 & 1498. & 19 & 1.84 & & 2.07 & 1.90 & & 0.47 & 0. & 51.97 & 0.06 & 0.1 & & 0.03 & 0.04 & 0. & 0.00 & 0.00 & \\
\hline & B3 & 2.07 & 1.71 & 1390.17 & 2.07 & 1.76 & 1400.17 & 2.08 & 1.79 & 1358.80 & 0.57 & 0.24 & 18.87 & 0.07 & 0.10 & 0.60 & 0.00 & 0.00 & 0.0 & 0.00 & 0.00 & 0.00 \\
\hline & B4 & 2.04 & 1.97 & 1310.2 & 2.11 & 1.76 & 1388.10 & 2.02 & 1.96 & 1390.30 & 0.5 & 0.44 & 39.47 & 0.30 & 0.08 & 0.86 & 0.00 & 0.00 & 0.0 & 0.00 & 0.00 & 0.00 \\
\hline & B5 & 2.06 & 2.02 & 1366.23 & 2.13 & 1.79 & 1361.63 & 2.03 & 1.86 & 1443.27 & 0.49 & 0.49 & 39.10 & 0.06 & 0.20 & 0.31 & 0.00 & 0.01 & 0.0 & 0.00 & 0.00 & 0.00 \\
\hline & B6 & 2.03 & 2.03 & 1343.2 & 2.10 & 1.91 & 1359.13 & 2.06 & 1.88 & 1340.33 & 0.82 & 0.74 & 96.77 & 0.13 & 0.07 & 1.85 & 0.00 & 0.00 & 0.00 & 0.00 & 0.00 & 0.00 \\
\hline & B7 & 2.10 & 1.74 & 1439.3 & 2.06 & 2.10 & 1271.97 & 2.06 & 1.77 & 1312.70 & 0.83 & 0.35 & 68.51 & 0.03 & 0.05 & 0.36 & 0.00 & 0.00 & 0.00 & 0.00 & 0.00 & 0.00 \\
\hline & B8 & 2.08 & 1.89 & 1416.17 & 2.05 & 1.88 & 1386.27 & 2.07 & 1.93 & 1309.40 & 0.54 & 0.85 & 72.37 & 0.03 & 0.03 & 0.04 & 0.00 & 0.00 & 0.00 & 0.00 & 0.00 & 0.00 \\
\hline & B9 & 2.07 & 1.78 & 1275.83 & 2.01 & 1.84 & 1158.93 & 2.22 & 1.70 & 1197.13 & 0.53 & 0.77 & 68.20 & 0.04 & 0.05 & 0.03 & 0.01 & 0.00 & 0.01 & 0.00 & 0.00 & 0.00 \\
\hline & $\mathrm{Se}$ & 2.06 & 1.87 & 1156.73 & 1.99 & 1.67 & 1317.60 & 2.07 & 1.57 & 1293.43 & 0.39 & 0.42 & 27.87 & 0.02 & 0.01 & 0.10 & 0.00 & 0.01 & 0.00 & 0.00 & 0.00 & 0.00 \\
\hline
\end{tabular}

Where: B1 to B9 are sweetpotato cultivar Beauregard, $\mathrm{Se}=$ I. setosa, $\mathrm{SPFMV}=$ Sweetpotato faeatherly mottle virus, $\mathrm{SPCSV}=$ Sweetpotato chlorotic stunt virus 


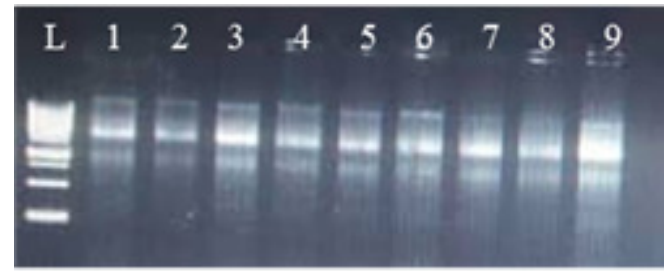

b

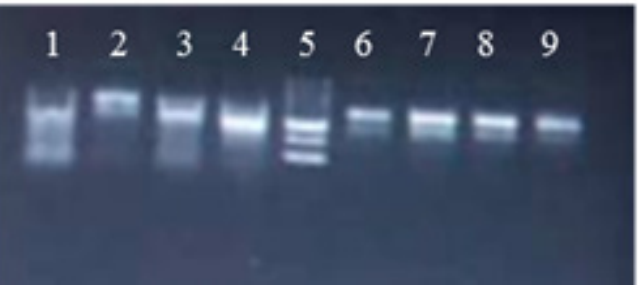

Figure 1. Integrity of RNA assessed on $1.2 \%$ agarose gel electrophoresis. Plate (a) depicts lanes for RNA from plant samples (1-9) extracted using original CTAB protocol by Lodhi et al. (1994), while plate (b) shows lanes for RNA from plant samples (1-9) extracted using our modification; Lane L = 1kb ladder.

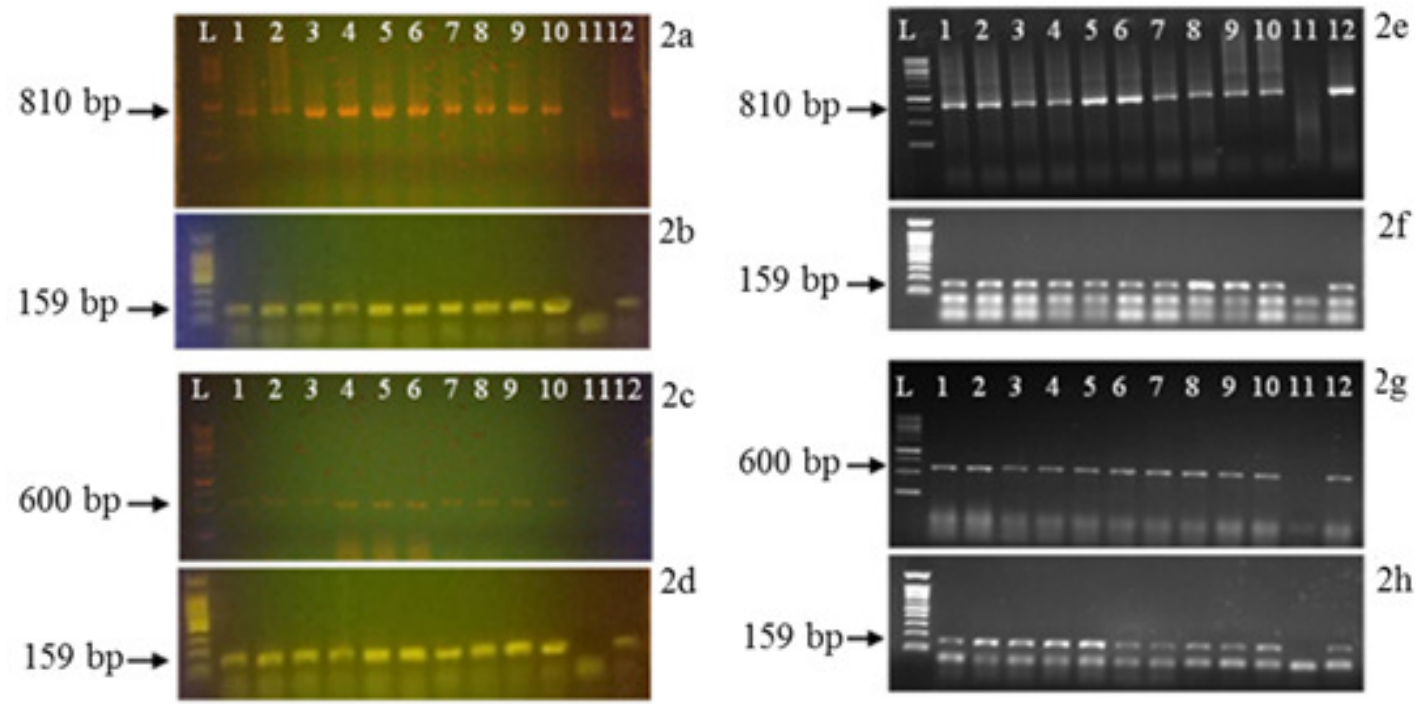

Figure 2. Gels of PCR showing amplified products using a miniPCR from RNA extracts incubated in liquid nitrogen for 1.5 hours (a-d) and using conventional RT-PCR from RNA extracts incubated at $4{ }^{\circ} \mathrm{C}$ for overnight (e-h). Plates (a) and (e) are depictions of SPFMV gel pictures, while (c) and (g) are depictions of SPCSV gel pictures; lanes $\mathrm{L}=1 \mathrm{~kb}$ ladder, 1-9 $=\mathrm{cv}$. Beauregard sweetpotato plants, $10=$ I. setosa, 11 = negative control and 12= positive control. Plates (b), (d), (f) and (h) are the host Cytochrome C oxidase reference gene. 
extraction method, which require elaborate and expensive laboratory procedures, with incubation periods ranging from 1-3 hours on -80 to $4{ }^{\circ} \mathrm{C}$ for overnight (Lodhi et al., 1994; Rott et al., 2001; Gasic et al., 2004). The new protocol is, thus good under SSA conditions where laboratory RNA extraction costs make the existing procedures prohibitive for timely and accurate field based detection.

The modified extraction procedure of sweetpotato tissue, yielded RNA of high purity, that was never contaminated nor degraded (Fig. 1). Our composite samples obtained from the top, middle and basal leaves ensured an even distribution of RNA in the extracts. This is in agreement with previous studies that mature and partially expanded leaves produce sufficient RNA extracts (Lodhi et al., 1994; Gasic et al., 2004). Lodhi et al. (1994) and Gasic et al. (2004) articulated that very young leaves yielded very poor nucleic acid extracts, because the rate of cell division in newly forming leaves is too high and hence viral replication cannot cope up with the speedy rate of plant cell division thus lower concentration of viral nucleic acid in such parts. Hence, young leaves should be avoided in any extraction work.

Incubation time. Since incubation is meant to precipitate out the nucleic acid from the sample (Sahu et al., 2012), we tried a variation on the incubation time period step after $6 \mathrm{M}$ $\mathrm{LiCl}$ was added to the sample, and then incubated in liquid nitrogen instead of incubation at $4{ }^{\circ} \mathrm{C}$ for overnight. We found out that the sweetpotato samples incubated in liquid nitrogen for 120 and 90 minutes efficiently yielded RNA extracts of competitive purity and concentration, compared to plant samples incubated at $4{ }^{\circ} \mathrm{C}$ for overnight (Table 2). This RNA was well amplified by RT-miniPCR, quite successfully in a similar way to incubation using the original procedure (Fig. 2).

Lodhi et al. (1994) postulated that addition of PVP to the extraction buffer, as has been done to modified protocol, clears out polyphenols deemed to be PCR blockers from the solution (Guillemaut and MaréchalDrouard, 1992; Ajmal-Iqbal et al., 2013). Similarly, such modified CTAB procedures containing hexadecyltrimethyl ammonium bromide (CTAB), polyvinyl pyrrolidine (PVP), and â-mercaptoethanol (Jaakola et al., 2001) are known to yield high quality RNA, which is amenable to downstream processes such as PCR.

Our study revealed that incubation periods of 75, 60, 45 and 30 minutes in liquid nitrogen did not yield sufficient RNA, both in purity and quantity (Table 2). This could be because these incubation periods were too short to allow for effective precipitation of RNA out of the samples. Sahu et al. (2012) postulated that the longer the incubation of samples at cold temperatures, the more the precipitation of the nucleic acid. Thus, insufficient incubation time for RNA to precipitate out of the samples also explains the lack of significant difference between the concentration of RNA for all samples incubated at $4{ }^{\circ} \mathrm{C}$ for overnight, and those incubated in liquid nitrogen for 120 and 90 minutes (Table 2).

For the two feasible incubation time periods in liquid nitrogen (120 and 90 minutes), as well as for the control (overnight at $4{ }^{\circ} \mathrm{C}$ ) the concentration was within the detection range

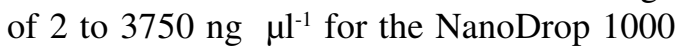
spectrophotometer model (Thermo Scientific, 2010) used.

Although the steps of re-suspending the pellet in $200 \mu \mathrm{l} 1 \mathrm{X}$ TE buffer containing $1 \%$ SDS; followed by re-suspension in $100 \mu$ of $5 \mathrm{M} \mathrm{NaCl}$ and $300 \mu \mathrm{l}$ of ice cold iso-propanol were omitted, our optimised extraction method yielded high quality virus genomic RNA with high concentration and purity (Fig. 1). This is because sweetpotato is a herbaceous perennial (Huamari, 1992; Ateka et al., 2004) with fewer polysaccharides, yet use of a high concentration of salts as used by Lodhi et al. (1994) is meant to remove polysaccharides associated with shrubs and woody perennials (Suzuki et al., 2003; Xu et al., 2010). 
With our modified protocol, 120 minutes and 90 minutes incubation time periods yielded RNA that exhibited an average RNA/protein contamination (260/280) ratio in the range of 1.997-1.978; and ratio chaotropic salt contamination (260/230) in the range of 1.852 -1.860 for samples taken from SPFMV infected plants. On the other-hand, samples taken from SPCSV infected plants yielded RNA extracts with RNA/protein contamination that averaged to 2.06; while chaotropic salt contamination ratio varied from 1.860-1.852. As stated in Thermo Scientific (2010), RNA is of high quality if the $260 / 280$ ratio is approximately 2.0 and the 260/230 ratio exceeds 2.0. On the other hand, $\mathrm{Xu}$ et al. (2010) found that RNA is of high quality if 260/280 and 260/230 ratios range between 1.7-2.2 and 1.4-1.8, respectively. Basing on Thermo Scientific (2010) and Xu et al. (2010), our protocol yielded sufficient RNA of high purity and this was further confirmed by the ease of 1 cDNA synthesis and eventual PCR amplification.

Results of the cDNA amplification using a portable miniPCR showed a high rate of success ( $100 \%$ overall), as determined by gel electrophoresis visualisation (Fig. 2). We were able to visualise amplicons successfully from the Bluegel visualisation unit for SPFMV (810 bp) and SPCSV (600 bp). These outcomes are similar to those we observed following RNA extraction, using the original protocol (Lodhi et al., 1994); and subsequent amplification of cDNA using a conventional PCR thermocycler at the laboratory level (Fig. 2). However, unlike the conventional PCR thermocycler, in the built-in power supply with the miniPCR thermocycler, the visualisation of band separation occured in real time and this shortened the electrophoretic time by up to 5 minutes; and avoided exposure to ethidium bromide and UV light by employing the GelGreen dye and detection with blue light.

González-González et al. (2019) observed that although the miniPCR is of a smaller size, it ably allows a full amplification protocol to be performed in a similar time as in a conventional thermocycler. Thus, RNA yielded by a modified protocol was of sufficient purity, further confirmed by ease of downstream application such as cDNA synthesis and RTminiPCR.

A study by Xu et al. (2010) revealed that reverse transcription is highly impaired by impurities and could interfere with cDNA synthesis. Since we produced clear bands for the amplicons for both SPFMV and SPCSV, it means that our protocol yielded RNA suited for downstream molecular procedure such as cDNA synthesis and eventual RT-miniPCR. Hence, this modified protocol and commercially available and simple nucleic acid amplification system have great potential for use in remote areas, where sweetpotato production is centred, but are devoid of dependable electricity and laboratory facilities. Even-then, RT-PCR analysis of Cytochrome C-oxidase (Cox) reference gene (Park et al., 2012) for cDNA synthesised from our RNA extracts furthermore demonstrated that there were no contaminants to interfere with reverse transcription or PCR reactions(Xu et al.,2010).

\section{CONCLUSION}

A portable protocol for extracting competitively refined RNA in a short time and under nontraditional laboratory methods has been successfully developed. Key changes in the routine procedures included incubation of samples in liquid nitrogen for 90 minutes, other than at $4{ }^{\circ} \mathrm{C}$ for overnight; and the use of a portable RT-miniPCR thermocycler for cDNA synthesis and amplification The alterations in the original procedures have resulted in reduction in incubation time from overnight to as low as 105 minutes. The purity of the RNA is comparable to the Lodhi et al. (1994) procedure; although the methodology still needs to be tested on DNA viruses and proper costing determined in order to recommend it for use. 


\section{ACKNOWLEDGEMENT}

We are greatly thankful to Bio innovate Africa - ICOPSEA (Integrating ICT in Commercial Production of Quality Sweetpotato Planting Material in East Africa) project for providing the funds to conduct this study.

\section{REFERENCES}

Adikini, S., Mukasa, S.B., Mwanga, R.O. and Gibson, R.W. 2016. Effects of sweet potato feathery mottle virus and sweet potato chlorotic stunt virus on the yield of sweetpotato in Uganda. Journal of Phytopathology 164(4):242-254.

Ajmal-Iqbal, I.A., Ahmad, H., Nadeem, M.S., Nisar, M. and Riaz, H. 2013. An efficient DNA extraction protocol for medicinal plants. International Journal of Biosciences 3(7):30-35.

Aritua, V., Legg, J.P., Smit, N.E.J.M. and Gibson, R.W. 1999. Effect of local inoculum on the spread of sweet potato virus disease: limited infection of susceptible cultivars following widespread cultivation of a resistant sweet potato cultivar. Plant Pathology 48(5):655-661.

Aritua, V., Bua, B., Barg, E., Vetten, H. J., Adipala, E. and Gibson, R.W. 2007. Incidence of five viruses infecting sweetpotatoes in Uganda; the first evidence of Sweet potato caulimo-like virus in Africa. Plant Pathology 56(2):324-331.

Aritua, V., Barg, E., Adipala, E., Gibson, R.W. and Vetten, H.J. 2008. Further evidence for limited genetic diversity among East African isolates of Sweet potato chlorotic stunt virus. Journal of Phytopathology 156(3): 181-189.

Ateka, E.M., Njeru, R.W., Kibaru, A.G., Kimenju, J.W., Barg, E., Gibson, R.W. and Vetten, H.J., 2004. Identification and distribution of viruses infecting sweet potato in Kenya. Annals of Applied Biology 144(3):371-379.

Clark, C.A., Davis, J.A., Abad, J.A., Cuellar, W.J., Fuentes, S., Kreuze, J.F., Gibson,
R.W., Mukasa, S.B., Tugume, A.K., Tairo, F.D. and Valkonen, J.P. 2012. Sweetpotato viruses: 15 years of progress on understanding and managing complex diseases. Plant Disease 96(2):168-185.

Gasic, K., Hernandez, A. and Korban, S.S. 2004. RNA extraction from different apple tissues rich in polyphenols and polysaccharides for cDNA library construction. Plant Molecular Biology Reporter 22(4):437-438.

Gibson, R.W., Mpembe, I., Alicai, T., Carey, E.E., Mwanga, R.O.M., Seal, S.E. and Vetten, H.J. 1998. Symptoms, aetiology and serological analysis of sweet potato virus disease in Uganda. Plant Pathology 47(1): 95-102.

González-González, E., Mendoza-Ramos, J.L., Pedroza, S.C., Cuellar-Monterrubio, A.A., Márquez-Ipiña, A.R., Lira-Serhan, D. and Alvarez, M.M. 2019. Validation of use of the miniPCR thermocycler for Ebola and Zika virus detection. PloS One 14(5):1-16. Guevara, E.E., Frankel, D.C., Ranaivonasy, J., Richard, A.F., Ratsirarson, J., Lawler, R.R. and Bradley, B.J. 2018. A simple, economical protocol for DNA extraction and amplification where there is no lab. Conservation genetics resources 10(1): 119-125.

Guillemaut, P. and Maréchal-Drouard, L. 1992. Isolation of plant DNA: A fast, inexpensive, and reliable method. Plant Molecular Biology Reporter 10(1):60-65.

Huamari, Z. 1992. Systematic botany and morphology of the sweetpotato plant. International Potato Center, Lima, Peru. Technical Information Bulletin 25:1-22.

Jaakola, L., Pirttilä, A.M., Halonen, M. and Hohtola, A. 2001. Isolation of high quality RNA from bilberry (Vaccinium myrtillus L.) fruit. Molecular Biotechnology 19(2):201203.

Kreuze, J.F., Savenkov, E.I. and Valkonen, J.P.T. 2002. Complete genome sequence and analyses of the subgenomic RNAs of Sweet potato chlorotic stunt virus reveal several new features for the genus 
Crinivirus. Journal of Virology 76(18): 9260-9270.

Kwak, H.R., Kim, M.K., Shin, J.C., Lee, Y.J., Seo, J.K., Lee, H.U., Jung, M.N., Kim, S.H. and Choi, H.S. 2014. The current incidence of viral disease in Korean sweet potatoes and development of multiplex RT-PCR assays for simultaneous detection of eight sweet potato viruses. The Plant Pathology Journal 30(4):416.

Lodhi, M.A., Ye, G.N., Weeden, N.F. and Reisch, B.I. 1994. A simple and efficient method for DNA extraction from grapevine cultivars andVitis species. Plant Molecular Biology Reporter 12(1):6-13.

Moyer, J.W. and Salazar, L.F. 1989. Viruses and virus-like diseases of sweet potato. Plant Disease 73(6):451- 455.

Mukasa, S.B., Rubaihayo, P.R. and Valkonen, J.P.T. 2006. Interactions between a crinivirus, an ipomovirus and a potyvirus in coinfected sweetpotato plants. Plant Pathology 55(3):458-467.

Mukasa, S.B., Rubaihayo, P. R.and Valkonen, J. P. T. 2003. Incidence of Viruses and Virus like Diseases of Sweetpotato in Uganda. Plant Disease 87(4):329-335.

Park, S.C., Kim, Y.H., Ji, C.Y., Park, S., Jeong, J. cheol, Lee, H.S. and Kwak, S.S. 2012. Stable Internal Reference Genes for the Normalization of Real-Time PCR in Different Sweetpotato Cultivars Subjected to Abiotic Stress Conditions. PLOS ONE 7(12):1-9.

Rott, M.E. and Jelkmann, W. 2001. Characterization and detection of several filamentous viruses of cherry: adaptation of an alternative cloning method (DOPPCR), and modification of an RNA extraction protocol. European Journal of Plant Pathology 107(4):411-420.

Sahu, S. K., Thangaraj, M. and Kathiresan, K. 2012. DNA extraction protocol for plants with high levels of secondary metabolites and polysaccharides without using liquid nitrogen and phenol. ISRN Molecular Biology 2012:1-6

Sakai, J., Mori, M., Morishita, T., Tanaka, M., Hanada, K., Usugi, T. and Nishiguchi, M. 1997. Complete nucleotide sequence and genome organization of sweet potato feathery mottle virus ( $\mathrm{S}$ strain) genomic RNA: the large coding region of the $\mathrm{P} 1$ gene. Archives of Virology 142(8):1553-1562.

Ssamula, A., Okiror, A., Avrahami Moyal, L., Tam, Y., Gaba, V., Gibson, R.W. and Wasswa, P. 2020. Factors influencing reversion from virus infection in sweetpotato. Annals of Applied Biology 176(2):109-121.

Suzuki, Y., Hibino, T., Kawazu, T., Wada, T., Kihara, T. and Koyama, H. 2003. Extraction of total RNA from leaves of Eucalyptus and other woody and herbaceous plants using sodium isoascorbate. Biotechniques 34(5):988-993.

Thermo Scientific. 2010. Nucleic AcidNanoDrop Spectrophotometers. Booklet. Thermo Fisher Scientific publisher, Wilmington, DE, USA. pp. 1-30.

Tugume, A.K., Cuellar, W.J., Mukasa, S.B. and Valkonen, J.P. 2010. Molecular genetic analysis of virus isolates from wild and cultivated plants demonstrates that East Africa is a hotspot for the evolution and diversification of Sweet potato feathery mottle virus. Molecular Ecology 19(15): 3139-3156.

Wasswa, P., Otto, B., Maruthi, M.N., Mukasa, S.B., Monger, W. and Gibson, R.W. 2011. First identification of a sweet potato begomovirus (sweepovirus) in Uganda: characterization, detection and distribution. Plant Pathology 60(6):1030-1039.

$\mathrm{Xu}$, J., Aileni, M., Abbagani, S. and Zhang, P. 2010. A reliable and efficient method for total RNA isolation from various members of spurge family (Euphorbiaceae). Phytochemical Analysis 21(5):395-398. 